\title{
Kesesuaian Timor Leste dengan Komunitas ASEAN
}

\author{
Miftahul Choir \\ Undergraduate Student of International Relations Department at Universitas Katolik Parahyangan \\ miftahulofficial@gmail.com
}

\begin{abstract}
Abstrak
Sebagai satu-satunya organisasi regional yang hadir di kawasan Asia-Pasifik, ASEAN terbentuk secara konstruksi sosial dimana identitas, nilai dan norma menjadi penentu utama dalam dinamika regional. Dalam sejarahnya, kekuatan imaterial menjadi faktor utama dalam menentukan keanggotaan ASEAN. Hal ini dibuktikan dengan masuknya Vietnam, Kamboja dan Myanmar sebagai anggota ASEAN di tahun 1990. Akan tetapi, hal ini justru berbeda ketika Timor Timur mendaftarkan diri sebagai anggota ASEAN di tahun 2011. Beberapa negara menolak kehadiran Timor Timur dikarenakan dikhawatirkan negara anggota tersebut menjadi beban ekonomi bagi organisasi regional ini, meskipun secara identitas dan nilai Timor Timur dan negara anggota ASEAN saat ini memiliki banyak kesamanaan. Keadaan ini menunjukan bahwa dalam kasus Timor Timur ini, ASEAN telah mereduksi faktor imaterial dan menempatkan faktor material didepan dalam penerimaan anggota. Untuk membuktikan argumen tersebut, tulisan ini akan menggunakan teori multilateralisme yang diperkenalkan oleh John Ruggie dengan argumen dibutuhkan ekspektasi keuntungan timbal-balik dari organisasi regional. Tulisan ini melihat bahwa secara material Timor Timur belum memberikan keuntungan terhadap ASEAN sehingga faktor imaterial dengan mudah dapat tereduksi.
\end{abstract}

Keywords: ASEAN, Multilateralism, Regionalism, Material Power

Menjelang pertemuan tingkat tinggi ASEAN ke-33 di Singapura pada November yang akan datang, isu keanggotaan Timor Leste akan kedalam organisasi regional ini akan kembali dibahas. Sejak 2011, Timor Leste telah mengajukan keanggotaannya kedalam ASEAN. Namun, beberapa negara menyuarakan penolakan terhadap keanggotaan Timor Leste. Singapura, Vietnam, dan Thailand merupakan beberapa negara yang beranggapan keanggotaan Timor Leste di ASEAN akan berdampak buruk bagi keberlanjutan organisasi regional yang saat ini tengah menjalani fase integrasi regional. Disisi lain, Indonesia, Filipina, dan Malaysia menyambut baik keanggotaan Timor Leste. Alasan identitas seperti sesama bangsa terjajah, penganut nilai katolik serta advokasi terhadap perjuangan hak asasi manusia menjadi alasan ketiga negara tersebut mendukung keanggotaan Timor Leste di ASEAN. Meskipun pada kasus ini ASEAN terbagi 
menjadi dua kubu, isu ini masih belum menjadi bahasan utama regional dan masih dikesampingkan dalam pertemuan-pertemuan ASEAN.

Ruggie menjelaskan multilateralisme dalam organisasi internasional harus disertai dengan hubungan timbal balik yang saling tidak terpisahkan. Ruggie mendefinisikan terlebih dahulu bahwa multilateralisme adalah hubungan terkoordinasi antara tiga negara atau lebih yang memiliki prinsip-prinsip yang sama. Melalui definisi ini, Ruggie berargumen bahwa multilateralisme adalah salah satu bentuk karakateristik atau sifat dari sebuah institusi. Hal ini juga mengartikan bahwa tidak semua institusi sampai pada tahap multilateralisme. ${ }^{1}$ Keohane menjelaskan secara lebih rinci bahwa dalam sebuah institusi yang bersifat multilateral perlu dicapai hubungan timbal balik. Hubungan timbal balik ini Keohane definisikan sebagai standar dari masing-masing negara untuk menjalankan sebuah kerjasama. Keohane membagi hubungan timbal balik ini menjadi dua, specific reciprocity dan diffuse reciprocity. ${ }^{2}$ Dalam specific reciprocity, dibutuhkan adanya kesteraan antar mitra kerjasama dengan kerugian yang terbatas. Umumnya, specific reciprocity ini perlu dicapai secara bilateral terlebih dahulu sebelum dapat mencapai tahap diffuse reciprocity. Dalam tahap diffuse reciprocity, hubungan timbal balik menjadi lebih tinggi dan mengikat hubungan antarnegara dalam institusi multilateral tersebut. Keohane juga menjelaskan bahwa kondisi yang mendukung terjadinya hubungan timbal balik dalam suatu institusi diantaranya keinginan untuk bekerjasama, proyeksi masa depan, dan jumlah anggota dalam institusi multilateral tersebut.

Secara rasional, kubu Singapura tidak salah apabila beranggapan bahwa keanggotaan Timor Leste di ASEAN akan membebani organisasi ini. Alasannya sangat sederhana: tidak ada hubungan yang saling menguntungkan antara Timor Leste dengan negara anggota ASEAN lainnya, justru kehadirannya akan memberikan beban. Asumsi kubu Singapura ini tentunya didasari oleh kemampuan ekonomi Timor Leste yang tidak sekuat negara anggota ASEAN lainnya. Meskipun kaya akan sumber daya alam, kekayaan gas Timor Leste justru dinikmati oleh Australia. Bahan pokok negara ini sendiri masih sangat tergantung pada Indonesia serta kualitas sumber daya manusianya masih belum bisa menunjang peningkatan aktivitas perekonomian. Hubungan dagang antara negara anggota ASEAN pun tergolong masih lemah untuk mencapai specific reciprocity sehingga apabila dilanjutkan ketahap yang lebih maju, Timor Leste diprediksi tidak akan memberikan keuntungan bagi negara anggota ASEAN.

Singapura juga tentu menyadari bahwa ASEAN kini sedang dalam fase penguatan integrasi regional melalui peresmian ASEAN Pillar Community yang meliputi perekonomian, politik, dan sosial budaya. Dalam menjalankan masyarakat ekonomi ASEAN, beberapa negara anggota ASEAN yang memiliki kekuatan ekonomi lebih kuat dari Timor Leste mengalami berbagai kendala. Perdagangan bebas yang dipromosikan oleh masyarakat ekonomi ASEAN dinilai menyakiti ekonomi beberapa negara, menganggu stabilitas internal hingga merusak

\footnotetext{
${ }^{1}$ John Ruggie, "Multilateralism: Anatomy of Institutions," International Organizations 46, no. 3 (Summer 1992):.

${ }^{2}$ Robert Keohane, "Reciprocity in International Relations," International Organizations 40, no. 1 (December 1986):.
} 
lapangan pekerjaan. Negara yang memiliki kapabilitas ekonomi yang kuat seperti Singapura pun mengalami kendala dalam menjalani masyarakat ekonomi ASEAN karena harus menanggung beban yang dipikul oleh empat negara terbaru ASEAN - Vietnam, Kamboja, Laos dan Myanmar. Meskipun kondisi keempat negara tersebut semakin membaik, Singapura tetap mempersepsikan kelompok negara tersebut sebagai free riders di ASEAN dan tentunya Singapura tidak ingin menambah beban lebih banyak. Peran Singapura sebagai penggagas masyarakat ekonomi ASEAN ini juga memperkuat alasan Singapura untuk harus memastikan keberadaan komunitas ekonomi ini. Meskipun telah terstruktur secara formal, institusi ASEAN masih belum cukup memberikan sanksi pada Timor Leste apabila terbukti gagal untuk mengikuti mekanisme ASEAN ketika bergabung nanti.. Keohane berargumen bahwa apabila tidak ada norma atau obligasi yang mengikat perilaku negara dalam organisasi multialteral, maka sikap timbal balik menjadi instrumen yang cukup untuk memaksa suatu negara mengikuti mekanisme organisasi. ${ }^{3}$

Fase yang dialami ASEAN saat ini jelas berbeda pada fase ketika ASEAN menerima keanggotaan Kamboja, Laos, Vietnam dan Myanmar pada dekade 1990. Meskipun menuai berbagai kontroversi, ASEAN tidak membutuhkan waktu yang lama untuk menerima keanggotaan empat negara tersebut. Politik pasca perang dingin yang menuntut ASEAN untuk bersikap lebih fleksibel dan terbuka terhadap kerjasama menjadi alasan penandatangan deklarasi Bangkok untuk menerima keanggotaan negara Asia Tenggara daratan yang penuh dengan pelanggaran HAM. Dengan itikad baik, ASEAN memiliki pandangan optimis bahwa dengan memasukan keempat negara tersebut, ASEAN akan berkonsekuensi pada meningkatnya perkembangan masing-masing negara dan akan menjadi mitra kerjasama bagi negara anggota ASEAN lainnya. Pengaruh Tiongkok yang semakin besar di wilayah itu juga menjadi alasan karena ASEAN yang terbangun atas politik perang dingin ingin menciptakan kawasan yang damai dan kohesif tanpa adanya kekuatan yang dominan. Melihat dua fase yang berbeda tersebut, tentu berbeda pula persyaratan keanggotaan ASEAN.

Tulisan ini akan memaparkan serangkaian analisis mengenai ketidaksiapan Timor Leste untuk menjadi anggota ke-11 di ASEAN. Melalui kerangka teori John Ruggie dan Robert Keohane, tulisan ini menemukan bahwa tidak ada hubungan yang bersifat timbal balik atau saling menguntungkan antara negara anggota ASEAN dengan Timor Leste. Bagian pertama tulisan ini akan menunjukan pengalaman Timor Leste dalam organisasi internasional sebagai perbandingan kapabilitas yang dimiliki ketika akan bergabung dengan ASEAN. Kemudian akan dianalisis pula kemampuan Timor Leste untuk memenuhi tiga pilar komunitas ASEAN, terutama pilar masyarakat ekonomi ASEAN yang disponsor oleh Singapura mengingat pilar tersebut merupakan prioritas utama ASEAN saat ini dalam rangka mencapai integrasi regional. Pada penjelasan mengenai kesiapan Timor Leste untuk mengikuti mekanisme komunitas ASEAN, akan terlihat bahwa tidak ada hubungan bilateral yang cukup antara negara anggota ASEAN dengan Timor Leste sehingga hubungan timbal balik akan sulit terjadi. Tetapi justru akan

\footnotetext{
${ }^{3}$ Ibid, 2
} 
menjatuhkan Timor Leste pada kondisi free riders. Perbedaan fase yang dialami ASEAN akan termasuk kedalam analisis mengenai integrasi ASEAN, dan pada bagian akhir akan ditemukan jawaban atas ketidakmampuan Timor Leste untuk bergabung dengan ASEAN.

\section{Timor Leste dalam Organisasi Internasional}

Untuk membahas partisipasi Timor Leste dalam organisasi internasional, perlu dijelaskan terlebih dahulu kebijakan luar negeri yang dijalankan oleh Timor Leste. Kebijakan luar negeri Timor Leste bersifat bandwagoning foreign policy. Dalam hal ini, kebijakan luar negeri yang dikeluarkan sangat bergantung pada aktivitas yang dilakukan oleh Australia dan Indonesia. ${ }^{4}$ Kondisi tersebut tidak lepas juga pada fakta bahwa Timor Leste masih digolongkan sebagai negara kecil, baik secara material maupun kapabilitas dalam menjalankan hubungan internasional. Sebagai negara kecil, Timor Leste hanya menjalankan kebijakan luar negerinya dengan target jangka pendek dikarenakan intensitas pembentukan keputusannya tidak sebesar yang dimiliki oleh negara besar. ${ }^{5}$ Selain itu, sebagai negara kecil, kebijakan luar negeri yang dapat diambil oleh Timor Leste sangat bergantung pada sistem internasional. ${ }^{6}$ Sejak kemerdekaannya pada tahun 2002, pasukan perdamaian PBB masih menetap di Timor Leste hingga tahun 2013. Hal ini menunjukan bahwa Timor Leste belum menemukan kemandirian dalam menjalankan tugas negara sehingga masih membutuhkan bantuan aktor lain. Kepentingan Indonesia dan Australia juga lebih diutamakan dibandingkan dengan kepentingan Timor Leste. Sehingga, akan terlihat bahwa meskipun Timor Leste bergabung dengan berbagai organisasi internasional, keanggotaan yang dimiliki hanya sebatas status. Bukti keterlibatan Timor Leste dalam organisasi tersebut masih tergolong rendah. Hal ini juga tidak lepas pada fakta bahwa Timor Leste merupakan negara yang baru berdiri kurang dari 20 tahun dan sering diterpa oleh instabilitas domestik. Kondisi tersebut berkonsekuensi pada Timor Leste berfokus pada pemulihan internal negara dibanding kebijakan luar negeri.

Timor Leste telah bergabung dengan organisasi atau forum internasional antara lain PBB dan termasuk dalam kelompok G-77 didalamnya, Organisasi Konfederasi Islam, meskipun Timor Leste penganut katolik. Karena letaknya yang berada diantara Asia Tenggara dan kawasan Pasifik serta memiliki ras Melanesia, Timor Leste juga bergabung dengan Pacific Island Forum sejak tahun 2002. Keanggotaan dalam PIF ini memberikan Timor Leste peran sebagai penghubung antara Asia Tenggara dengan negara-negara kepulauan di Pasifik. ${ }^{7}$ Di kawasan Asia Tenggara, saat ini Timor Leste merupakan anggota tidak tetap dari ASEAN, dan telah ikut serta dalam Treaty of Amity and Cooperation. Timor Leste juga bergabung dengan mekanisme

\footnotetext{
${ }^{4}$ Anthony Smith, "Constraint and Choices: East Timor as Foreign Policy Actors," New Zealand Journal of Asian Studies 7, no. 1 (June 2005):

${ }^{5}$ Ibid 4

${ }^{6}$ David Willis, "Timor-Leste's Complex Geopolitics: The Local, the Regional and the Global," in Timor Leste: The Local, the Regional, and the Global, ed. Sarah Smith, vol. 1 (Dili: Timor Leste Studies Association, 2015).

${ }^{7}$ Jose Kai Lekke, "Acting West, Looking East: Timor-Leste's Growing Engagement with the Pacific Islands Region," in Regionalism, Security \& Cooperation in Oceania, ed. Rouben Azizian, Carleton Cramer, and Daniel Inouye (Honolulu: Asia Pacific Center for Asia Studies, 2016).
} 
ASEAN di kawasan Asia Pasifik diantaranya dengan berpartisipasi dalam ASEAN Foreign Minister Meeting dan ASEAN Regional Forum.

Partisipasi yang dilakukan oleh Timor Leste kepada negara-negara di kawasan Pasifik cukup positif. Konteks sejarah Timor Leste yang merupakan bekas negara jajahan dan mengalami serangkaian pelanggaran HAM menjadi pembangun kerjasama dengan negara AsiaPasifik. Bentuk kerjasama yang dilakukan Timor Leste berupa pemberian bantuan pembangunan terhadap negara Pasifik yang rawan konflik, dan memberikan solusi-solusi yang kontekstual. ${ }^{8}$ Hal ini juga ditentukan oleh kesamaan persepsi ancaman yang dimiliki oleh negara-negara Pasifik dengan Timor Leste. Agenda keamanan Timor Leste saat ini adalah keamanan masyarakat, pergerakan manusia secara ilegal, permasalahan lingkungan, dan keamanan maritim. ${ }^{9}$ Dalam praktisnya, dalam keorganisasian di Pasifik, Timor Leste memberikan bantuan kemanusiaan terhadap negara rawan konflik di Pasifik serta membantu pengadaan sekretariat Melanesia Spearhead Group (MSG). Tidak hanya didalam konteks regional, Timor Leste juga turut menyuarakan kepentingan negara-negara kepulauan Pasifik dalam forum PBB yang tergabung dalam blok G-77 Small Island Developing States (SIDS) dengan advokasi hak asasi manusia dan permasalahan non-tradisional yang dibawa oleh Timor Leste.

Pemaparan diatas menunjukan bahwa Timor Leste cukup aktif dalam organisasi internasional, baik secara regional ataupun secara universal. Namun, keterlibatan tersebut dinilai masih belum cukup untuk bergabung dengan ASEAN. Alasan yang mendasari keterlibatan Timor Leste dengan negara-negara di kawasan Pasifik adalah kesamaan tingkat dan kapabilitas negara-negara didalamnya. Negara Pasifik memiliki kebijakan luar negeri yang pragmatis dan berorientasi pada pemenuhan kapabilitas untuk menstabilkan kondisi domestik. Mengingat kondisi domestik merupakan ancaman utama dalam keamanan negara Pasifik dibandingkan dengan ancaman yang bersifat eksternal. Sehingga tidak ada alasan bagi negara Pasifik untuk menolak kehadiran Timor Leste. Sedangkan dengan negara ASEAN, kestabilan domestik bukan lagi ancaman utama. Lingkungan eksternal masih menjadi sumber dari ancaman untuk negara anggota ASEAN. Berkaca dari aktivtas yang dilakukan oleh Timor Leste di kawasan Pasifik, Timor Leste tidak bersuara terhadap ancaman eksternal yang didapati oleh negara kepulauan. Kemampuan yang dimiliki oleh Timor Leste saat ini hanya mampu untuk memenuhi hubungan dengan negara yang dianggap memiliki kesamaan kapabilitas material.

\section{Kesesuaian Timor Leste kedalam Komunitas ASEAN}

Alasan yang melatarbelakangi ASEAN untuk menolak keanggotaan Timor Leste adalah karena Timor Leste dianggap tidak mampu menyesuaikan diri dengan mekanisme yang telah dirancang ASEAN melalui komunitas ASEAN yang diresmikan sejak tahun 2007. Komunitas ASEAN ini kemudian terbagi menjadi tiga yang meliputi politik-keamanan, sosial-budaya, dan

\footnotetext{
${ }^{8}$ Ibid

${ }^{9}$ Rebecca Strating, "East Timor's Emerging National Security Agenda: Establishing "Real" Independence," Asian Security 9, no. 3 (November 2013):.
} 
ekonomi. Dalam pilar politik-keamanan menekankan pada implementasi dari mekanisme ASEAN dalam menyelesaikan konflik-konflik regional. Penggunaan mekanisme tersebut pada umumnya menggunakan cara-cara yang bersifat non-militer dan sudah beberapa kali dilakukan oleh Timor Leste dengan instrmen lokakarya dan dialog. ${ }^{10}$ Dalam proses integrasi pilar politikkeamanan dibutuhkan pula kondisi politik domestik yang stabil. Khusus untuk pilar sosialbudaya dan ekonomi, kedua pilar tersebut berfokus pada satu benang merah yang sama yaitu kualitas sumber daya manusia. Kualitas sumber daya yang cukup akan menunjang adanya kerjasama atau integrasi yang bertujuan untuk melestarikan warisan intelektual kawasan. Sementara untuk pilar ekonomi akan berkontribusi sebagai penguat rantai kerjasama antar negara anggota.

Kehadiran komunitas ASEAN menunjukan bahwa ASEAN telah berada dalam tahap baru menuju integrasi regional. Sehingga, keanggotaan Timor Leste di ASEAN tidak dapat dibandingkan dengan Kamboja, Laos, Myanmar dan Vietnam ketika mendaftarkan diri diri kedalam ASEAN pada dekade 1990. Keanggotaan Timor Leste sendiri dikhawatirkan karena masih sedikit staf birokrasi yang kompeten untuk menjalani serangkaian pertemuan ASEAN. ${ }^{11}$ ASEAN terbangun dengan logika politik perang dingin yang membatasi keanggotaan untuk negara-negara komunis atau non-demokratis di Asia Tenggara. Setelah perang dingin berakhir, ASEAN mencoba bersikap lebih fleksibel dan mempersepsikan kehadiran negara-negara tersebut menjadi peluang untuk bekerjasama. Meskipun keempat negara tersebut memiliki serangkaian kasus pelanggaran HAM, pemerintahan komunis hingga kondisi politik domestik yang belum stabil, ASEAN menanggap dengan mengintegrasikannya kepada mekanisme ASEAN maka keempat negara tersebut dapat berperilaku selayaknya negara ASEAN dan dapat menjadi mitra kerjasama. Selain itu, pendaftaran untuk keanggotaan ASEAN pada kala itu bersifat undangan dari negara anggota ASEAN dan tidak ada mekanisme-mekanisme khusus untuk penerimaan anggota.

Hal tersebut berbeda dengan kondisi ASEAN masa kini. ASEAN telah berubah menjadi organisasi regional yang lebih terstruktur, formal, dan memiliki regulasi-regulasi yang mengatur tindakan negara, meskipun struktur dan regulasi tersebut tetap dijalankan secara informal sesuai dengan identitas ASEAN. Setelah sukses mengkonsolidasi negara-negara kawasan Asia Tenggara yang ditandai dengan masuknya keempat negara Indochina, ASEAN menyadari bahwa tahap selanjutnya adalah memperkuat ikatan antar negara-negara anggota. Mengambil contoh dari organisasi regional lainnya, restrukturisasi menjadi lebih ketat dan teratur untuk memperkuat ikatan tersebut. Hal ini ditujukkan dengan diresmikannya ASEAN Charter pada tahun 2008 yang menyediakan kerangka kerja, fondasi hukum yang kuat, serta menetapkan target-target yang harus dicapai ASEAN dengan jelas. Keberadaan ASEAN Charter ini juga mempengaruhi keanggotaan Timor Leste karena telah dibentuk ASEAN Consulatation on Working Group yang

${ }^{10} \operatorname{Ibid} 9$

${ }^{11}$ Ibid 4

ISSN 0216-5031

Copyright (@) 2019 Universitas Katolik Parahyangan 
bertugas untuk menyelidiki kesiapan Timor Leste untuk bergabung dengan ASEAN. ${ }^{12}$ Melalui mekanisme tersebut, proses keanggotaan negara baru ke ASEAN kian menyerupai Helsinski Process yang diterapkan oleh Uni Eropa. Ketika Kamboja, Laos, Myanmar dan Vietnam bergabung dengan ASEAN, keempat negara tersebut tidak harus melewati proses birokrasi yang sedemikian ketat. Keberadaan ASEAN Charter ini juga kemudian melahirkan konsep komunitas ASEAN. Melalui komunitas ASEAN ini, negara anggota ASEAN berharap kerjasama dapat bersifat lebih fungsional sehingga dapat memperkuat integrasi antar negara.

Konsep komunitas ekonomi ASEAN secara umum mengarahkan integrasi regional dengan menghilangkan batas-batas yang ada untuk menjalankan aktivitas ekonomi seperti perdagangan bebas. Untuk mencapai tahap tersebut, negara anggota ASEAN tentunya harus memiliki kesiapan secara ekonomi agar tidak tertinggal dengan negara lainnya. Singapura, selaku negara yang paling giat mempromosikan masyarakat ekonomi ASEAN, perlu memastikan bahwa tiap negara anggota harus mampu pula mencapainya. Hal inilah yang kemudian melatarbelakangi Singapura sangat menolak kehadiran Timor Leste di ASEAN karena dapat membebani proses integrasi yang sedang dijalankan. ${ }^{13}$ Armstrong berargumen bahwa negara kecil akan kesulitan bersaing dengan negara-negara industri untuk liberalisasi ekonomi. ${ }^{14}$ Timor Leste masih memiliki kesulitan dalam mengontrol perekonomian dalam negeri, dan akan kalah bersaing dengan negara-negara industri baru di kawasan Asia Tenggara. Selain itu, keterbukaan terhadap pengaruh asing dalam perekonomian yang lemah juga akan mengakibatkan Timor Leste menjadi sangat rawan untuk terjadi krisis. Apabila krisis tejadi pada salah satu anggota komunitas, dampaknya akan terasa pada seluruh negara anggota komunitas tersebut.

Permasalahan yang ada pada Timor Leste adalah rendahnya kapabilitas ekonomi Timor Leste untuk menjalankan ekonominya secara mandiri sehingga dinilai tidak mampu menyesuaikan dengan masyarakat ekonomi. Untuk mendapatkan sumber bahan makanan dan bahan pokok lainnya, Timor Leste sangat menggantungkannya pada Indonesia. ${ }^{15}$ Hingga saat ini ekspor dari Indonesia memenuhi $42 \%$ dari produk Timor Leste. Untuk Indonesia, kondisi tersebut memang menguntungkan, untuk negara anggota ASEAN lainnya ini jelas menunjukan bahwa Timor Leste masih belum mampu untuk menukar produksi dalam negerinya kepada pihak luar. Kapabilitas dagang Timor Leste hanya sebatas negara-negara yang memiliki letak yang tidak jauh seperti Indonesia dan Australia. Hal ini dapat dibuktikan dengan tingkat perdagangan Timor Leste dengan negara-negara anggota ASEAN lain selain Indonesia hanya mencapai 7.7\%, 2.8\% dan 2.7\% untuk masing-masing Singapura, Thailand dan Malaysia. Hal ini menunjukan bahwa belum adanya hubungan dagang yang baik antara Timor Leste dengan negara anggota

\footnotetext{
${ }^{12}$ Zegi Dias Prameswari, "Penyebab Penolakan Singapura Terhadap Konsesus Keanggotaan Timor Leste Di ASEAN," Jurnal Analisis Hubungan Internasional 7, no. 1 (January 2018):.

${ }^{13}$ Ibid 12

${ }^{14}$ Harvey Armstrong and Robert Read, "Trade and Growth in Small States: The Impact of Global Trade Liberalisation," The World Economy 21, no. 4 (June 1998):.

${ }^{15}$ Laurentino Soares, "Development and Foreign Aid in Timor-Leste after Independence," in Truth and Reconciliation in Timor-Leste, Indonesia, and Melanesia, ed. David Webster (University of Calgary Press).
} 
ASEAN sehingga belum dapat dikatakan adanya hubungan saling membutuhkan diantara mereka.

Kebijakan Timor Leste juga saat ini mengarah kepada pembangunan ekonomi dan infrastruktur sehingga mengesampikan pembangunan kualitas sumber daya manusia. Hal ini berkonsekuensi pada alokasi dana yang ditujukan untuk sektor pertanian, pendidikan dan kesehatan jauh berada di bawah sektor pembangunan infrastruktur. ${ }^{16}$ Human Development Index (HDI) yang dimiliki oleh Timor Leste hanya mencapai angka 0.625, dan berada pada peringkat ke 132. Tren dari HDI pun tidak mengalami peningkatan yang signifikan bahkan cenderung stagnan. Berada jauh di bawah negara ASEAN seperti Singapura, Brunei, Malaysia yang menempati posisi 9, 39 dan 57 serta dapat dikategorikan sebagai negara dengan kualitas sumber daya yang baik. Sehingga Meskipun kesempatan mencari pekerjaan dibuka untuk warga Timor Leste di negara-negara ASEAN, besar kemungkinan akan berkonsekuensi pada menjamurnya pekerja kasar yang kemudian berkembang menjadi pengganguran dan kriminal akibat gagal mendapat pekerjaan dikarenakan kalah saing dengan negara lain yang memiliki kualitas manusia yang lebih baik. Kualitas sumber daya ini juga menunjukan bahwa dalam jangka waktu yang cukup panjang Timor Leste akan terus berada dalam produksi agraria, belum menuju tahap industri. Mayoritas negara ASEAN merupakan negara agraria dan memiliki perkembangan yang lebih maju dari Timor Leste. Hal ini mengakibatkan produk-produk Timor Leste akan kalah saing dengan produk lokal dari masing-masing negara terkait produksi agraria. Negara anggota ASEAN lain pun akan kesulitan untuk menjual produk industri dikarenakan permintaan untuk mesin dan faktor produksi industri lainya masih rendah, dan kualitas manusia untuk mengoperasikannya belum mencukupi.

Mengenai pilar politik-keamanan, sistem pemerintahan Timor Leste yang belum stabil akan menyulitkan terintegrasinya DENGAN mekanisme ASEAN meskipun secara praktis Timor Leste telah mempraktikan mekanisme tersebut dalam hubungan intenasional Untuk melihat kesiapan Timor Leste maka diperlukan untuk melihat sistem institusi yang berjalan di negara ini. Sistem institusi ini akan menentukan kapabilitas pejabat politik untuk menjalankan pemerintahannuya. ${ }^{17}$ Sistem pemerintahan di Timor Leste saat ini adalah semi-presidensial. Presiden Timor Leste yang seharusnya memiliki andil dalam pemerintahan justru tidak mempunyai peran dalam pemerintahan dan tidak memiliki kapabilitas untuk penentuan pejabat pemerintah. Kondisi ini kemudian mengakibatkan sempat terjadinya kudeta di Timor Leste pada tahun 2006 untuk menggulingkan Alkatiri dan Xanana Gusmao serta membuat Timor Leste masih harus bergantung pada pemerintahan transisi PBB hingga tahun 2013. Keberadaan pemerintahan transisi PBB ini juga menunjukan bahwa Timor Leste masih belum dapat berdaulat secara penuh. Pemerintahan yang berjalan saat ini juga dinilai tidak demokratis karena

\footnotetext{
${ }^{16}$ Dennis Shoesmith, "REMAKING THE STATE IN TIMOR-LESTE: THE CASE FOR CONSTITUTIONAL REFORM," 17th Biennial Conference of the Asian Studies Association of Australia in Melbourne:.

${ }^{17}$ Dennis Shoesmith, "REMAKING THE STATE IN TIMOR-LESTE: THE CASE FOR CONSTITUTIONAL REFORM," 17th Biennial Conference of the Asian Studies Association of Australia in Melbourne:.
}

ISSN 0216-5031

Copyright @ 2019 Universitas Katolik Parahyangan 
mengurangi kebebasan berpendapat dan mengurangi batasan-batasan yang dimiliki oleh aktor politik.

\section{Kesimpulan}

Berdasarkan analisis diatas, dapat disimpulkan bahwa dalam waktu dekat Timor Leste tidak akan meraih keanggotaan di ASEAN. Hubungan timbal balik antarnegara anggota ASEAN dengan Timor Leste hingga kini masih belum tercapai. Hal ini dapat ditujukan dengan rendahnya tingkat perdagangan antaranegara. Bergabung dengan ASEAN tidak akan meningkatkan hubungan dagang karena tidak ada ketertarikan dari negara-negara anggota ASEAN untuk menjalankan hubungan dagang dengan Timor Leste. Hal ini tentunya disebabkan oleh perbedaan karakteristik aktivitas ekonomi antarnegara serta rendahnya kapabilitas ekonomi dan kualitas manusia yang dmiliki oleh Timor Leste sehingga negara anggota ASEAN enggan melakukan kerjasama. Secara politis, Timor Leste juga masih mengalami berbagai permasalahan sehingga tidak mampu mengikuti mekanisme pilar politik-keamanan.

\section{Bibliography}

Armstrong, Harvey, and Robert Read. "Trade and Growth in Small States: The Impact of Global Trade Liberalisation." The World Economy21, no. 4 (June 1998): 563-85.

Keohane, Robert. "Reciprocity in International Relations." International Organizations40, no. 1 (December 1986): 1-27.

Lekke, Jose Kai. "Acting West, Looking East: Timor-Leste's Growing Engagement with the Pacific Islands Region." In Regionalism, Security \& Cooperation in Oceania, edited by Rouben Azizian, Carleton Cramer, and Daniel Inouye, 110-21. Honolulu: Asia Pacific Center for Asia Studies, 2016.

Prameswari, Zegi Dias. "Penyebab Penolakan Singapura Terhadap Konsesus Keanggotaan Timor Leste Di ASEAN." Jurnal Analisis Hubungan Internasional7, no. 1 (January 2018): 107-16.

Ruggie, John. "Multilateralism: Anatomy of Institutions." International Organizations46, no. 3 (Summer 1992): 561-98.

Shoesmith, Dennis. "REMAKING THE STATE IN TIMOR-LESTE: THE CASE FOR CONSTITUTIONAL REFORM." 17th Biennial Conference of the Asian Studies Association of Australia in Melbourne. 
Smith, Anthony. "Constraint and Choices: East Timor as Foreign Policy Actors." New Zealand Journal of Asian Studies7, no. 1 (June 2005): 15-36.

Soares, Laurentino. "Development and Foreign Aid in Timor-Leste after Independence." In Truth and Reconciliation in Timor-Leste, Indonesia, and Melanesia, edited by David Webster, 93-108. University of Calgary Press.

Strating, Rebecca. "East Timor's Emerging National Security Agenda: Establishing "Real” Independence." Asian Security9, no. 3 (November 2013): 185-210.

Willis, David. "Timor-Leste's Complex Geopolitics: The Local, the Regional and the Global." In Timor Leste: The Local, the Regional, and the Global, edited by Sarah Smith, 237-43. Vol. 1. Dili: Timor Leste Studies Association, 2015. 